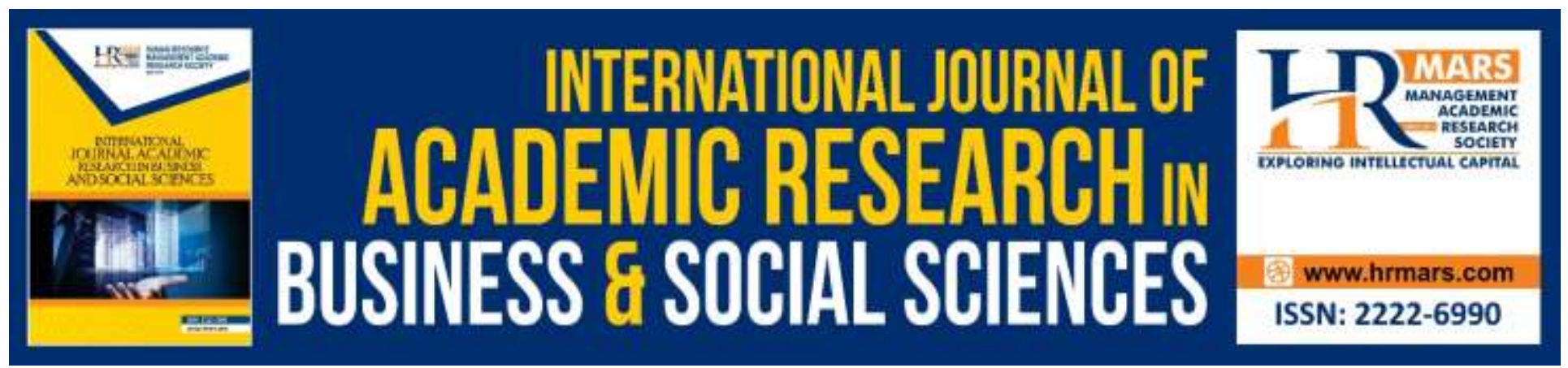

\title{
Death Penalty for Drug Trafficking Cases in Malaysia: Theory vs Reality
}

Nasreen Miza Hilmy Nasrijal, Ekmil Krisnawati Erlen Joni, Afzan Nor Talib

To Link this Article: http://dx.doi.org/10.6007/IJARBSS/v10-i3/7069

DOI:10.6007/IJARBSS/v10-i3/7069

Received: 04 February 2020, Revised: 21 February 2020, Accepted: 13 March 2020

Published Online: 28 March 2020

In-Text Citation: (Nasrijal et al., 2020)

To Cite this Article: Nasrijal, N. M. H., Joni, E. K. E., \& Talib, A. N. (2020). Death Penalty for Drug Trafficking Cases in Malaysia: Theory vs Reality. International Journal of Academic Research in Business and Social Sciences, 10(3), 533-547.

\section{Copyright: (C) 2020 The Author(s)}

Published by Human Resource Management Academic Research Society (www.hrmars.com)

This article is published under the Creative Commons Attribution (CC BY 4.0) license. Anyone may reproduce, distribute, translate and create derivative works of this article (for both commercial and non-commercial purposes), subject to full attribution to the original publication and authors. The full terms of this license may be seen

at: http://creativecommons.org/licences/by/4.0/legalcode

Vol. 10, No. 3, 2020, Pg. 533 - 547

http://hrmars.com/index.php/pages/detail/IJARBSS

JOURNAL HOMEPAGE

Full Terms \& Conditions of access and use can be found at http://hrmars.com/index.php/pages/detail/publication-ethics 


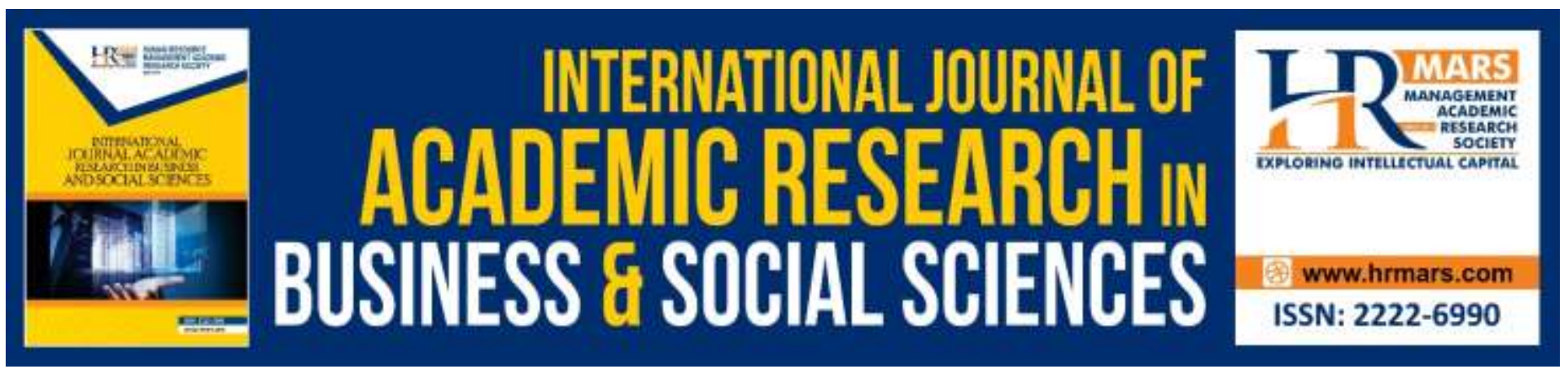

\title{
Death Penalty for Drug Trafficking Cases in Malaysia: Theory vs Reality
}

\author{
Nasreen Miza Hilmy Nasrijal ${ }^{1}$, Ekmil Krisnawati Erlen Joni², \\ Afzan Nor Talib ${ }^{3}$ \\ ${ }^{1,2}$ Department of Law, Universiti Teknologi MARA (UiTM) Cawangan Melaka, Malaysia, ${ }^{3}$ Faculty of \\ Business and Management, Universiti Teknologi MARA (UiTM) Cawangan Melaka Malaysia
}

\begin{abstract}
Death penalty is the most extreme punishment for a crime and has been berated as heartless and barbaric. Nations implementing death penalty are scorned upon and pressured to replace death penalty with more humane punishment. Although drug trafficking in Malaysia is punishable by death, there is no guarantee that all accused persons charged for drug trafficking will be hanged to death. Judges in Malaysia are extremely cautious in meting out death penalty and would only do so in the absence of reasonable doubt. This paper examines drug trafficking cases reported over two decades to ascertain whether Malaysia has liberally executed death penalty on drug traffickers. Empirical analysis supported by doctrinal research was carried out on drug trafficking cases reported in three leading law journals in Malaysia from 1991 to 2012. Analysis of the cases on drug trafficking in Malaysia revealed that a significant number of cases were concluded with the acquittal of the accused persons. While enforcing death penalty is not arbitrarily done, acquittals in drug trafficking cases are indicative of need for improvements.
\end{abstract}

Keywords: Death Penalty, Drug Trafficking, Acquittal, Conviction.

\section{Introduction}

Drug trafficking is a global problem as it endangers the nation and leads to drug-related crimes. Realizing the detrimental effects of drug trafficking, the Malaysian government had imposed death penalty for drug trafficking since 1975 where the punishment was life imprisonment and/or whipping or death. It was only in 1983 that the law was revised, making drug trafficking punishable by mandatory death penalty under section 39B of the Dangerous Drugs Act 1952 (DDA) (revised 1983) in line with the Malaysian government's declaration on drug misuse as a threat to national security (Teoh, 2003). When moving the Bill to increase the punishment for drug trafficking, the government noted that life imprisonment and whipping were not effective deterrent measures against drug trafficking activities, as the volume of drug trafficking activities continued to increase between 1980 and 1983. The government acknowledged that the drug menace was widespread and had affected 
INTERNATIONAL JOURNAL OF ACADEMIC RESEARCH IN BUSINESS AND SOCIAL SCIENCES Vol. 10, No. 3, March, 2020, E-ISSN: 2222-6990 @ 2020 HRMARS

people of all races and ages (Rani, 2007). The drug traffickers were considered as traders of death, causing destruction and misery. Their acts were regarded as acts of treason, and hence, could not be pardoned or sympathized (Parliamentary Debate, 1983).

The aim to impose such severe sentence on drug trafficking offences is to act as a deterrent measure and to reduce the occurrence of drug-related offences (Ho Mooi, 2007). Mandatory death penalty is intended to incapacitate the offender and to serve as a deterrent to potential drug traffickers from committing the same offence (Clarkson, Keating \& Cunningham, 2007). Death penalty was perceived as the most effectual punishment due to its permanent and forceful nature that it would be appropriate to deter heinous crimes such as rape, murder, armed robbery and treason (Kwai, 1981). In addition, imposing such severe sentence was deemed to be necessary for the protection of public interests and to emphasize public disapproval with the punishment imposed as an indication of the gravity of the offense as stated in Chang Liang Sang v Public Prosecutor (1982) ML 231. However, with recent developments and awareness on human rights issues, the Malaysian government has been urged to discard death penalty. A significant issue needs to be addressed before any attempt in amending the law: has death penalty achieved its deterrent effect and fulfilled its objectives to reduce drug trafficking activities? This paper examines section 39B DDA cases which were reported in three leading law journals in Malaysia to determine whether death penalty had achieved its objective as deterrent measure to reduce drug trafficking activities. Findings from this study revealed that despite the severe punishment, drug trafficking offences continue to escalate. Further, the number of cases in which the accused persons were acquitted almost equalized those which were convicted. While the theory is that drug trafficking is punishable by death in Malaysia, the reality is that death penalty was not executed in a significant number of cases. Based on the statistical analysis, this study further expounds on the reasons for acquittal in drug trafficking cases.

\section{Materials and Methods: Examining Conviction and Acquittal in Drug Trafficking Cases}

The objective of a criminal justice system is that the guilty person should be punished and that utmost precaution is taken to ensure that no innocent person is ever convicted (MPH Rubin, 1996). Judges have been warned to be extremely cautious in meting out a punishment, particularly when the sentence is severe and irreversible such as death penalty. William Blackstone (1975) aptly stated that "It is better that ten guilty persons escape than that one innocent suffer." The criminal justice process exists for the conviction and punishment of the guilty and the acquittal of the innocent, with broad protection of the society as a whole (Nini, 1998). The process of justice in Malaysia is stipulated in Section 180 of Criminal Procedure Code (2012) (CPC):

(i) When the case for the prosecution is concluded, the court shall consider whether the prosecution has made out a prima facie case against the accused.

(ii) If the court finds that the prosecution has not made out a prima facie case against the accused, the court shall record an order of acquittal.

(iii) If the court finds that a prime facie case has been made out against the accused on the offence charged, the court shall call upon the accused to enter his defence.

In order to convict the accused under section 39B (2), the prosecution has a burden to prove a prima facie case against the accused; that there is a case to be answered. To prove a prima facie case against the accused under section 39B (1)(a) and to enable conviction under section 39B(2) of DDA, the prosecution bears the burden of proving the following ingredients: (i) the drug or substance is a 
INTERNATIONAL JOURNAL OF ACADEMIC RESEARCH IN BUSINESS AND SOCIAL SCIENCES Vol. 10, No. 3, March, 2020, E-ISSN: 2222-6990 @ 2020 HRMARS

dangerous drug under s.2 of the Act, and which is listed in the First Schedule to the Act; (ii) the weight of the dangerous drug as stated in the charge; and (iii) the accused was trafficking in dangerous drugs. Failure to prove the above ingredients would result in the accused being acquitted (Hisham, 2006). In the case Public Prosecutor v Lye \& Anor (2012) 4 AMR 57 the court explained that: "pursuant to section 180 (2) of the CPC a prima facie case is established if the prosecution has adduced credible evidence proving each ingredient of the offence, which unrebutted or unexplained would warrant their conviction". Meanwhile in the case PP v Muniandy (2012) 2 CL 1064 the court held that:

"It is well settled that the test at the end of the prosecution's case is "prima facie case" based on a maximum evaluation of evidence. The Federal Court reiterated this principle in our criminal jurisprudence in Mohan v PP (2011) 1 CLJ 805, and went on to add: "The evidence has to be scrutinized properly and not perfunctorily, cursorily or superficially. If the evaluation of the evidence results in doubts in the prosecution's case, then a prima facie case has not been made out. The defence ought not to be called merely to clear or clarify such doubts."

On the other hand, with regard to acquittal, in the case Mat v. PP (1963) 29 MLJ 263 the court held that:

"...to obtain an acquittal and discharge, the appellants need not convince the court that their evidence was more reliable than the prosecution's evidence. Even if the court did not believe the defence, but if the defence could raise a reasonable doubt, it was sufficient for them to be acquitted and discharged".

Therefore, at the close of the prosecution's case the judge must rule whether the prosecution has introduced sufficient evidence as a prima facie test. If the judge is satisfied that the prosecution has introduced sufficient evidence on every element, the judge then shifts the burden to the defendant to enter his defence (Sydney, 1991). The task of the prosecution to prove a prima facie case is heavily dependent on the investigations carried out by the investigation officer and his team. The quality of investigations carried out by the investigation officer and his team is vital to ensure the success of the prosecution's case. As for the accused, the skill and experience of the defence lawyers in raising a reasonable doubt or issues on technical flaws is important to secure an acquittal for the accused. (Malik, 2009).

Empirical analysis supported by doctrinal research was carried out on drug trafficking cases reported in three leading law journals in Malaysia from 1991 to 2012. The cases reported in these journals consist of facts of the case and grounds of the judgment which are primary sources in Malaysian law aside from the relevant pieces of legislation. Using purposive sampling, cases were selected based on two criteria: the charge was under section 39B DDA and the case had been concluded, with the judge deciding on the charge under section 39B. Specific keywords peculiar to drug trafficking cases were used in search of the relevant cases. Cases which were reported in multiple journals were collated as one and cases which had no conclusive judgment (e.g. a trial within a trial, cases merely on procedural issues without sentence being passed) were eliminated from the sample. A total of 626 cases were obtained and analyzed for, inter alia, the grounds for acquittal or conviction under section 39B, defences raised by the accused, demographic background of the accused, the types of drugs trafficked, where the drugs were discovered and the outcomes of appeals. Although not all cases on drug trafficking are reported in the law journals, the cases found are representative of the cases brought to the courts. The number of cases reported on section 39B had increased in twofold; from 30 cases in 1991 to 75 cases in 2012. Out of 626 cases, only 307 cases (49\%) resulted in conviction of 
INTERNATIONAL JOURNAL OF ACADEMIC RESEARCH IN BUSINESS AND SOCIAL SCIENCES Vol. 10, No. 3, March, 2020, E-ISSN: 2222-6990 @ 2020 HRMARS

the accused. As for the remaining cases, the accused persons were either acquitted or convicted under sections 6, 37 or 39A of the DDA, all of which do not entail death penalty. A total of 330 cases went up on appeal. At the appeal stage, a total of 114 convictions were overturned by the appellate courts. Findings on the grounds for such acquittals are presented in the following.

\section{Result and Discussion}

To succeed in convicting the accused for drug trafficking, the prosecution must prove these important ingredients: that the accused had possession of the drugs (to prove possession, it must be shown that the accused had custody and control over the drugs), that the accused had knowledge of the drugs and that the weight of the drugs exceeded the permitted limit. Evidence must be adduced to prove these ingredients, although the prosecution may also rely on one of the presumptions under the DDA to prove either possession or knowledge or weight in the absence of direct evidence. Absence of proof on the existence of these ingredients may result in failure to establish a prima facie case or if the evidences adduced are weak, it would enable the defence counsel to raise a reasonable doubt. Empirical analysis of the 626 drug trafficking cases selected in this study revealed various reasons; the common (but not exhaustive) reasons are as follows:

1. Lack of possession of drugs due to the place where the drugs were found

2. Flaws and discrepancies in the exhibits tendered as evidence of drugs

3. Break in the chain of evidence giving room for reasonable doubt

4. Prosecution's inability or omission to call a material witness

\section{Lack of Possession of Drugs due to the Place where the Drugs were Found}

For a person to be trafficking drugs, he/she must have the drugs in his/her possession. Possession, however, is easily rebutted. Empirical evidence shows that 65 (or 22.5\%) section 39B DDA cases ended in acquittal due to the prosecution's inability to prove possession. To prove possession, the prosecution must adduce evidence to demonstrate that the accused had knowledge of the item that was in his/her possession. The term possession has not been explicitly defined in the DDA. However, earlier cases have established that possession must be with mens rea to commit a crime; the possessor must be aware of his possession, must know the nature of the thing possessed and must have the power of disposal over it. Mere possession alone would not suffice to convict the accused. Exclusivity of possession is required to sustain a conviction for trafficking of the dangerous drugs under the DDA. In the case of Public Prosecutor $v$ Demin (2008) 4 ML 79, exclusive possession in the context of where the drug was found, the place must be exclusive to the accused, albeit being joint possession with more than one person having custody and control over the drugs. On the other hand, in the case of PP $\vee$ Madhavan (2009) 2 CL 209, the court held that possession of the drugs does not have to be exclusive, but in order to prove the element of possession, it must be proved that the one has the exclusive power to deal with the drugs.

The exclusivity of possession correlates with the place where the drugs were found. If the drugs were found on or in the accused's body, disproving possession or exclusive possession would be an arduous task for the accused. Of 626 cases analyzed, 35 cases involved drugs found on or in the body of the accused, out of which 31 cases resulted in the accused being convicted under section 39B. Drugs which were found in places where others have access - house, vehicle, a bag or the like - may not be easy to prove possession as reasonable doubts can be raised. In this study, out of 96 cases involving 
INTERNATIONAL JOURNAL OF ACADEMIC RESEARCH IN BUSINESS AND SOCIAL SCIENCES

Vol. 10, No. 3, March, 2020, E-ISSN: 2222-6990 @ 2020 HRMARS

drugs found discovered in a car, the accused persons were acquitted in 66 cases whereas 47 cases resulted in conviction. Out of a total of 113 cases involving drugs seized from a house, 54 ended in acquittals compared with 42 convictions. Conversely, where drugs were found in a bag, there were more convictions (91 cases) than acquittals (54 cases) - possibly due to the fact that the accused were caught handling, carrying or having the bag within close vicinity giving rise to possession.

Convicting an accused person for drug trafficking when the drugs were found in a house appeared to be a challenging chore for the prosecution because there are several defences to rebut the evidence or presumption on possession or exclusive possession: that the house belonged to someone else or rented by someone else and he was merely visiting, that other people can freely enter the house or the room in the house where the drugs were found, that someone else had the key to the house, that although the accused rented/owned the house, the drugs belonged to someone who had brought in the drugs without the knowledge of the accused. There are various cases to illustrate the lack of possession. In PP v Rashid \& 2 Ors. (1993) 4CLJ 266, the accused was acquitted from drug trafficking charges because allegation that he was the sole person with access and control of the room was rebutted by the presence of a third person, Nasir bin Usman, in the room when the drugs were found. Similarly, in the case of Bukhari v PP (2012) 7 CL 580, the contention that the appellant was the only person who had possession was refuted by the fact that the drug was found in an open space and visible to anyone who was in the room. The fact that the accused was the only occupant of the room in which the drugs were found does not ensure that the prosecution has proven exclusive possession when there was evidence that others had accessed to the room as shown in Yahaya v. PP (2012) 8 CLJ 405; (2013) 1 MLJ 180. Being the sole tenant of the rented house also does not amount to exclusive possession when evidence showed that customers of the adjacent workshop which the accused operated had access to the house (Sulong v PP (2012) 4 AMR 319). It is vital that the prosecution exclude exclude the possibility that other persons could have access to the place where the drugs were found (Yahaya v. PP (2013) 1 MLJ 180). For instance, in PP v. Muniandy (2012) 2 CLJ 1064 the prosecution had failed in its duty to establish that the accused was the exclusive occupier of the room or had exclusive use of the room in which the drugs were found to attract any inference of possession by the accused. This was due to the fact that the prosecution failed to produce the evidence of a third person, Murugan. The prosecution's failure to call the witness was fatal and created doubt in the prosecution's case.

When drugs were found in a car, the prosecution need to prove that the accused had possession and that the possession of the car was exclusively with the accused, eliminating the possibility that the drugs belonged to someone else who travelled in the car or owned the car if the accused was not the owner of the car. In PP v Ho Nee Fat (1995) 2CL 966, the accused raised doubts in prosecution's case by producing witnesses who testified that accused did not have exclusive possession of the car as others had access. Among the factors that need to be taken into account while carrying out the investigation are: who is the registered owner of the vehicle, the driver, the total number of people travelling in the car at the time of discovery of drugs, who has access to the car, in which part of the car were the drugs found and is there is any special compartment in car to store the drugs (which can be proven that the accused had knowledge of). The investigation officer is also under a duty to take the statements of everyone who travelled in the car as they are possible witnesses and their presence would be required to prove or disprove ownership of the drugs. The failure on the part of 
INTERNATIONAL JOURNAL OF ACADEMIC RESEARCH IN BUSINESS AND SOCIAL SCIENCES Vol. 10, No. 3, March, 2020, E-ISSN: 2222-6990 @ 2020 HRMARS

investigating officer to scrutinize and prove all the above facts might the benefit of doubt to the accused leading to an acquittal of the accused.

The exclusivity of vehicles could be challenged in the following circumstances: when the owner of vehicle could not be traced (if the accused was not the owner of the vehicle); there is evidence that other people such as the family members/friends/boyfriend/girlfriend of the accused had access to the vehicle in question prior to the arrest; there is evidence that the vehicle was not lock which enable other people access it.

In some cases, even though the case involved a huge amount of drugs, failure on the part of the prosecution to call witnesses to prove exclusive possession of the vehicles, resulted in the accused's acquittal (PP v Mahmud (2001) 3 CL 284). In addition, it is also important for the investigating officer to find the owner as well as the passenger of vehicle to testify or if this is not fulfilled the accused would be acquitted. This is highlighted in the case of PP V Ghazali \& Lain (2012) 1 CL 893 where failure of the prosecution to call Ani as a relevant witness in order to prove whether she is the owner of the car and rented it to Fauzi, caused the accused's acquittal. Similarly, in the case PP $v$ Hama \& Anor (2001) 4 CLJ 47, the judge acquitted the accused as the prosecution failed to call the owner of the car in which the drugs were found.

In sum, the failure of the prosecution to establish possession or exclusive possession is detrimental to his case and would be a ground for acquitting the accused. Possession or exclusive possession can be severely affected by the circumstances in which the drugs were seized - where the drugs were found and whether there was any evidence to show that the drugs were not conclusively in the possession, custody and control of the accused.

To succeed in convicting the accused for drug trafficking, the prosecution must prove these important ingredients: that the accused had possession of the drugs (to prove possession, it must be shown that the accused had custody and control over the drugs), that the accused.

\section{Flaws and Discrepancies in the Exhibits Tendered as Evidence of Drugs}

One of the ingredients under section 39B DDA to constitute trafficking is the presence of drugs listed under the DDA exceeding the prescribed limit. There must not be any doubts that the drugs seized were prohibited drugs under the DDA which had fulfilled the requirements as far as the types and weight of the drugs. Empirical evidence of the cases analyzed from 1991 to 2012showed that 34 cases $(11.8 \%)$ were acquitted due to discrepancies or doubts on the exhibit. Some of the situations where flaws or discrepancies on the identity of exhibit may arise are:

- the number of packets of drugs seize and received (Meng v PP (1992) 1 ML 322),

- the nature of drugs either powder or granular (PP v Mahmud (2001) 3 CL 284),

- discrepancies in the weight of the drugs (Public Prosecutor v Hong (2012) 8 ML 153),

- the possibility of a mix-up of exhibits (Public Prosecutor v Seng (1995) 4 MLJ 277), and

- inconclusive or questionable tests conducted by the chemist (Leong v PP (1992) 2ML 177) It is pertinent that the chemist report be impeccable to prove the weight and type of drugs. The test conducted by the chemist must provide conclusive evidence and eliminate any doubts on the exhibits. Among the most trafficked drugs seized in Malaysia is cannabis where a total of 325 cases involving cannabis were found in this study. Of the 325 cases, 149 cases resulted in acquittal of the accused. One of the reasons which contributed to the high number of acquittals the accused involving cannabis is because of the nature of cannabis which can be questioned as to its weight, 
INTERNATIONAL JOURNAL OF ACADEMIC RESEARCH IN BUSINESS AND SOCIAL SCIENCES Vol. 10, No. 3, March, 2020, E-ISSN: 2222-6990 @ 2020 HRMARS

content and test conducted. As a result, in most cases where the accused was acquitted involving cannabis, there were some contradictions in respect of the weight between the weight stated by the police investigating officer and that of the chemist. These contradictions statements made by the witnesses raised a reasonable doubt in the prosecution's case resulting the accused's acquittal. This could be seen in the case of Public Prosecutor v Chong Joon Hong (2012 8 MLJ 153 where the court acquitted the accused because the anomaly on the weight of the drugs, particularly the lesser net weight compared to the gross weight, was not explained in the re-examination of the chemist nor was the witness recalled to explain it. Similarly, in the case Heng v Raya (1992) 1 ML 327, there was a serious defect in the identity of the exhibits as there was a discrepancy in the weight of the drug exhibit between the weight recorded by the police and that of the chemist. In PP v Ismail (1992) 3CLJ 313 , failure of the prosecution to prove the weight of cannabis caused the accused to be acquitted. Another situation where doubts could be raised as regards the exhibit is the prosecution's failure to produce evidence of finger print test on the said drugs or to produce cogent justification as to why such test was not conducted. The omission on the part of investigating officer to dust the exhibits for finger print or to investigate any traces of drugs on the accused's clothes or under his nail resulting may result in the accused's acquittal as the prosecution did not prove possession (PP v Fom It Cheong (1991) 3CL 524). The same was also decided in the case Public Prosecutor $v$ Lye \& Anor (2012) 4 AMR 57 where the court held that:

'The absence of the fingerprints of the first accused on the box and its contents and the presence of an unknown person's fingerprints on the box forfeited the view that the prosecution had failed to establish that the first accused had at any point of time handled the box which contained the drugs...There was a serious doubt whether the box had been placed in the first accused car by an unknown person without the first accused having knowledge of the content'.

Thus, even though the drugs may appear to be of a huge volume, it is futile if the chemist report is questionable or there are discrepancies as regards the drugs which would raise reasonable doubts.

\section{Break in the Chain of Evidence Giving Room for Reasonable Doubt}

In establishing a prima facie case against the accused, the prosecution must prove not only that the exhibits were drugs fulfilling the prescribed weight under the DDA but also that the handling of the exhibits are accounted for, dispelling any possibilities that the exhibits were tampered. Of the 289 cases which resulted in acquittal, there were 33 cases $(11.4 \%)$ where there were breaks in the chain of evidence. It is gravely unfortunate when acquittal had to be granted due to the investigating officer's omission in exercising care and diligence while handling the investigation. One of the examples of poor handling of exhibits is when the drugs were kept by the arresting officer for a long duration upon seizure of the drugs from the accused without handing them over to the investigating officer. In Satar v PP (1991) 2MLJ 194, the accused was acquitted because there was a break in the chain of evidence as a result of the prosecution's failure to provide evidence on why the drugs were kept by the arresting officer for 24 hours before handing them to the investigating officer.

In PP v Lim Bong Kat \& Anor (1992) 3CLJ 380, the counsel for the accused had produced newspaper report and photos of press conference of the arrest. The photos showed markings on the packets of drugs but no evidence was produced by the prosecution as to who made the markings. This gave rise to reasonable doubts as to the exhibits and substantiated the argument of the counsel for the 
accused that someone else had handled the packets of drugs. The accused was acquitted due to the break in the chain of evidence.

The break in the chain of evidence may also be due to not only the investigating officer's fault but also that of the chemist. In PP $v$ Rashid \& 2 Ors (1993) 4CLJ 266, there was no evidence as to how long government chemist handled the drugs and steps taken to ensure safe custody. The chemist kept the drugs for 2 months and 17 days and the absence of evidence on the safekeeping of the drugs was a break in the chain of evidence resulting in the acquittal of the accused. The break in the chain of evidence could also be seen in the following cases: Abdullah bin Yaacob v PP (1991) 2MLJ 237; Public Prosecutor v Lye \& Anor (2012) 4 AMR 57; Public Prosecutor v Seng (1995) 4 ML 277.

The break in the chain of evidence exposed poor quality police investigatory practices and has been criticized by the court at all levels (Sydney L., 1991). The fundamental procedure on ensuring that all handling of the drugs are accounted for is sometimes overlooked and these omissions may be fatal to the prosecution's case. Therefore, the investigation officer should be cautious on this important procedure to prevent the prosecution's case from being jeopardized.

\section{Prosecution's Inability or Omission to Call a Material Witness}

In establishing a prima facie case, the onus is on the prosecution to adduce the relevant evidence. The evidences of material witnesses are necessary to support the prosecution's charge for drug trafficking against the accused. Failure of the prosecution to call the material witnesses would enable the counsel for the accused to invoke section 114(g) of the Evidence Act 1950 and the court is called upon to make adverse inference against the prosecution. The adverse inference would severely affect the prosecution's case as the failure to call a material witness would imply that the prosecution is suppressing evidence which is detrimental to the interest of the accused. In this study, it was found that the second highest reason for acquittal is contributed by the failure on the part of the prosecution to call the material witness. Out of 289 acquittals, 38 cases were acquitted for this reason.

The investigating officer is responsible to perform an important role in conducting investigation thoroughly in order to find a material witness who is an important witness to the case (Munusamy $v$ $P P$ (1987) 1 ML 492). There are a number of reasons for the prosecution's failure to call the material witness. In most cases, such failure correlates with the investigations carried out by the police investigating officer. It may happen due to the lackadaisical attitude of investigation officer which destroys the prosecution's case resulting in the acquittal of the accused person (Prosecutor $v$ Karim bin Ab Jaabar (2002) 2 MLJ 888). On another occasion, the investigating officer's omission in not making any effort to trace the owner of the car in which the drugs were found was fatal to the prosecution's case. This was because there were sufficient details of the owner's residential address and also the fact that the owner of the car was a wanted person by the Thai narcotic enforcement officers. Hence, there was reasonable doubt as to whom the drugs belonged or who placed the drugs in the car; such doubts could have been clarified had the prosecution called the owner of the car to give evidence as a witness (PP v Saare Hama \& Anor (2001) 4 CLJ 475).

Tracing a material witness can be rather daunting for the prosecution and among the common reasons for such failure is:

- witnesses may not be willing to co-operate 
INTERNATIONAL JOURNAL OF ACADEMIC RESEARCH IN BUSINESS AND SOCIAL SCIENCES Vol. 10, No. 3, March, 2020, E-ISSN: 2222-6990 @ 2020 HRMARS

- witnesses have moved/changed their addresses, changed their jobs, retired from their jobs or ran away for fear of the consequences against them

- limited resources (financial, expertise and manpower) to trace the witnesses

It is common when the accused was arrested, those associated with the accused might run away or hide for fear of being arrested by the investigating officer. When drugs are discovered in a vehicle, sometimes it is difficult to find the owner as the owner could have sold off the vehicle to another person without any documentation. Another hurdle is if the owner of the vehicle rented it to another person, but there were insufficient documents on the details of the driver. It is the duty of the investigating officer to find these witnesses and show that exhaustive attempts had been made to trace them to avoid adverse inference being made for failure to call these witnesses to give evidence in court. For example, in the case of Musa v PP (2012) 7 CLJ 16 the court found that the attempts made to trace a witness by the name of Zahariman were insufficient and unreasonable in the circumstances. The court in this case commented that it was a feeble attempt to trace Zahariman and that attracts adverse inference under s. 114(g) of the Evidence Act 1950. Evidence of the lackadaisical attitude of the investigating officer in tracing a material witness had also affected the prosecution's case resulting in acquittal of the accused in Hiang v PP (1995) 3 CL 1 FC and PP v Hamzah (2002) 1 LNS 59.

Adverse inference can also be made against the prosecution's case in the event that the prosecution neglects to secure the attendance of witnesses once the witnesses were offered to defence counsel at the close of prosecution's case. This could be seen in the case PP v Yusuf (2012) 3 CLJ 41 where three witnesses were offered to the defence by the prosecution. The prosecution failed to ensure their presence in court although the defence had expressed their wish to call them. The reason given by the prosecution that the witnesses could not be traced as they were Indonesians was not acceptable to absolve them from their duty in securing their attendance as the witnesses had been previously arrested and brought to the police station. Therefore, the court acquitted the accused.

Another important aspect to prove exclusive possession in respect of vehicles is by calling the material witness. This could be seen in the case in the case Pendakwaraya v Nordin (2001) 1 AMR 855 where the court held that by failing to call a material witness, the prosecution had failed to show exclusive custody and control of the van on the part of the accused. In acquitting the accused the judge said:

"...The absence of Mohd Yusoff in the prosecution's case has left many questions unanswered. Therefore I must say with respect that the prosecution had failed to discharge the onus encumber upon them to exclude the possibility of another person having access to the said van. The other person could have been none other than Mohd Yusof who could have been responsible for the said impugned drugs...the onus is not on the defence to prove possibility of access by others but on the prosecution to exclude such possibility".

In sum, it is essential that the investigating officer conducts thorough investigation and that the prosecution secure the attendance of material witnesses (either as the prosecution witness or to be offered to the defence) to prevent adverse inference. The investigation can be challenged if a material witness was not called or his statement was not taken in the process of investigation as this could have absolved the accused from the crime. When dealing with a crime punishable by death, 
INTERNATIONAL JOURNAL OF ACADEMIC RESEARCH IN BUSINESS AND SOCIAL SCIENCES

Vol. 10, No. 3, March, 2020, E-ISSN: 2222-6990 @ 2020 HRMARS

the courts would not treat errors or omissions lightly and would acquit the accused on any reasonable doubt.

\section{Defenses for the Accused Leading to an Acquittal}

It is imperative to analyze the common defences raised by the counsels for the accused which led to the acquittal of the accused. When conducting investigations, the investigating officer needs to be objective and prepared for various possibilities on the commission of the crime. Without a clear mind, the investigating officer may not be aware of the probability of the accused's version on the crime which would lead to an acquittal when the counsel for the accused raised reasonable doubts in putting forward the accused's version of the crime. By studying the defences commonly raised by the accused, the prosecution can be better prepared in presenting a water-tight and an irrefutable case against the accused to ensure a conviction.

Based on the section 39B DA cases analyzed from 1991 to 2012, among the defences or line of defences frequently raised by the accused are as follows:

- that the accused had no knowledge of the presence of drugs (85 cases or $15.7 \%$ )

- that the accused did not have exclusive possession (37 cases or $6.8 \%$ )

- that there was no act of trafficking drugs (48 cases or $8.9 \%$ )

- that the accused was an innocent or momentary carrier (24 cases or $4.4 \%$ )

The defence of absence of knowledge on the drugs is the most frequently used defence; out of 85 cases in which this defence was raised, 34 cases resulted in acquittal. It is necessary for the prosecution to prove knowledge of the nature of drugs as mens rea of specific intent to traffic in drugs. A person cannot be guilty of a crime if he had no intention of committing a crime. However, as intention or the guilty mind is an intangible element, section 37 of the DDA allows knowledge to be presumed in a number of circumstances. Reliance on presumption solely is said to weaken the prosecution's case and needs to be avoided as much as possible because it could discourage thorough police investigations.

A person is presumed to have possession and knowledge of the drugs when he/she is found to have custody and control over the drugs or anything containing the drugs. This statutory presumption is laid down in section 37(d) DDA. Even though section 37(d) specifically provides that a person found in possession of a drugs is "deemed to have known the nature of such drug" the court have weaken this presumption by reinserting a fairly narrow knowledge requirement into the law. In the case Public Prosecutor $v$ Goh Yeong Hock (1988) MLJ 185 the accused and his wife were charged with carrying 9,736.19 grams of heroin. The accused' bags had false bottom that contained heroin and the couple carried about $\$ 3000$ (US) in four difference currencies. The trial judge noted that, under presumptions established by section 37(d) and section 37(da)(i) DDA, they had custody and control and thus presumed knowledge of the said drugs. The defendant claimed that they believed they were smuggling counterfeit US dollars to the United Kindom, for which they were paid $\$ 5,000$. The court in acquitting the two accused found that they did not know the bags contained heroin. Although the accused admittedly believe that they were smuggling counterfeit money establishing general guilty mind, the requirement for trafficking is one of specific and not merely general intent.

In order to prove knowledge, the prosecution could use some inferences. Therefore, the court would analyse whether the conduct of the accused was sufficient to infer that he or she had knowledge on the said dugs. In PP v Leila Fatemi \& Another Case (2012) 7 CLJ 623 the court found that the conduct 
INTERNATIONAL JOURNAL OF ACADEMIC RESEARCH IN BUSINESS AND SOCIAL SCIENCES Vol. 10, No. 3, March, 2020, E-ISSN: 2222-6990 @ 2020 HRMARS

of the accused did not amount to having knowledge of illicit drugs in her possession. The very fact that both the bags were not padlocked gave rise to the inference that both accused did not know at all about the presence of the concealed drugs inside the specially modified compartments inside each bag. Further, the very spontaneous action of the accused in allowing PW7 (a prosecution witness) to open and search the contents of her bag without any hesitation strengthened the inference that she had no knowledge of the drugs concealed in the bag. At the same time, there was also possibility of access by other persons to the bags resulting in the drugs being put into the specially modified compartments of the bags without the knowledge of both the accused.

Some actions of the accused may not necessarily amount to presumption of his guilty mind or having knowledge of the committing the crime under section 39B. The fact that the accused ran away upon being confronted by police officers cannot be presumed to be knowledge of him having drugs in his possession. In PP v Maudgin bin Alipudin (1994) 1 CLJ 398 as well as PP v Tay Bee Seng (1993) $1 \mathrm{CLJ} 526$, the conduct of the accused trying to escape when confronted by plain clothes policemen was not sufficient to prove guilt. It could be a situation he ran because he thought someone chases him or wish to harm him or he ran because he believed that he was wanted by the policeman for committing other types of offence.

Findings in this study also showed that the absence of knowledge is one of the most frequent defences raised by the defence counsel at the appellate level. This defence was put forward in 43 cases at the Court of Appeal, 9 cases at the Federal Court and another 3 cases at the Supreme Court. The fact that a number of cases were acquitted showed that some of the defences were not given due consideration by the trial court hence leading to acquittal at the appellate stage by the highest court.

The defence of non-possession or non-exclusive possession is often used when the drugs were discovered in a car or a house. Although section 37(g) DDA allows presumption that the occupier of a premises has knowledge of the drugs found concealed in any premises, the presumption is rebuttal if the defence counsel can challenge the exclusivity of the possession of the premises in question by showing others had access to the premises. Judges do take judicial notice of the fact that the traditional Malaysian custom of living is to live in large extended family units. Therefore, by showing that someone else had access to the premises/vehicle where the drugs were discovered is sufficient to raise reasonable doubts on possession of drugs (Public Prosecutor $v$ Chuan (1985) ML 318; Yahaya v. PP (2012) 8 CLJ 405; PP v Hoe (1994) 2CLJ 85). In the case of PP v Fom It Cheong (1991) $3 \mathrm{CLJ} 524$ the prosecution failed to establish that the accused had the care and management of the house. The accused could not be deemed as the occupier as other people had access to the house. When drugs are found in a vehicle, the defences utilized by the counsel for the accused are: that the accused had no possession or exclusive possession of the vehicle and had no knowledge of the drugs in the vehicle. By virtue of section 37(h) DDA, when a dangerous drug is found "concealed in any compartment specially constructed for this purpose on any vehicle" it is presumed to have been concealed with the knowledge of the owner. This presumption is restricted as compared with the more general presumption under section 37(d), which is not applicable for drugs found in vehicles. The courts have ruled that a car cannot be a container of drugs although drugs were found in it because "that would twist and overstretch the language beyond its common usage" (Hawae \& Satu Lagi v PP (2012) 1 LNS 135 ; Hamid (1982) ML 132). Thus, knowledge could only be presumed when the drugs are actually found in a specially constructed compartment in the car as opposed to being 
found merely at the backseat of the car or in the boot of the car. In PP v Mak Yoke Kuen (2012) 10 CLJ 674 the court held the mere presence of the accused in the BMW car in the absence of any other evidence was insufficient to prove she knew that the packages were concealed in the compartment behind the steering wheel. The fact that the packages could not have been detected by a search carried out by SP3 with the aid of a police sniffer dog clearly showed the packages were very well concealed and could not be easily detected by the police let alone a lay person. In the absence of any knowledge of the packages it could not be said that they were in the accused's custody or control. Similar decision was also found in the case PP v Saare Hama \& Anor (2001) 4 CL 475.

The lack of an act amounting to trafficking is another usual defence raised by the accused. Out of 46 cases in which the defence of 'no act of trafficking' was raised, 33 cases ended in acquittal of the accused compared with only 13 convictions. The offence of trafficking is proved either by direct evidence or by way of presumption applying section 37 (da). The prosecutor must prove an over act on the part of the accused (Section 2 of DDA). In some cases, it is difficult to prove trafficking as the investigating officer arrested or ambushed the accused person prematurely; for example, the accused was arrested at the stage of negotiation for the price of drugs before an act of trafficking is present and the public prosecutor failed to give evidence that sale a sale transaction was concluded the time of arrest (Public Prosecutor v Abdullah (2005) MLU 503). In this situation defence counsel could use passive possession as the defence and it only attract the punishment under section 39A(2) of DDA.

The fact that the accused is transporting a large quantity of drugs from one point to another does not make him a trafficker. Whether he is trafficker in those circumstances depends on the facts and circumstances of the given case, including the quantity of the drugs and any transaction the accused proposed to enter into. Thus, the prosecution carries the legal burden to prove that the accused intended to transfer the drugs to another person in other to succeed to establish trafficking as mentioned by section 2 of the DDA (PP v Hasbi b M Kusin \& Anor (2008) 7 MLJ 331).

The defence of an innocent or momentary carrier is usually raised when the accused was caught with the drugs concealed in his/her bag or packages. Of the 24 cases, only 8 cases using the defence of innocent or momentary carrier ended in acquittal as compared with 16 cases where conviction was granted.

Reliance on the statutory presumptions is not safe for the accused, particularly as the presumption is easily rebuttable. The investigating officer needs to discover and utilize more concrete evidence to restrict reliance on the statutory presumptions. Meticulous and thorough investigation would facilitate the prosecution in eliminating possibilities of defences raised which would give room for reasonable doubt. By doing so, the number of acquittals could be reduced and resources for a full trial can be saved.

\section{Conclusion}

There are a number of reasons for the acquittal of the accused charged under section 39B and the statistics for acquittal is on the high side. Major concerns are on the integrity of the police work in the gathering of evidence, the quality of investigation as well as protection of the exhibits from the time of seizure of the drugs until trial is disposed of. Such misconduct would severely affect and be detrimental to the prosecution's case resulting in the acquittal of the accused person. The high rate of acquittals frustrates the government's intention in imposing mandatory death penalty on drug 
INTERNATIONAL JOURNAL OF ACADEMIC RESEARCH IN BUSINESS AND SOCIAL SCIENCES

Vol. 10, No. 3, March, 2020, E-ISSN: 2222-6990 @ 2020 HRMARS

traffickers to reduce drug trafficking activities. An urgent active measure must be taken to improve the level of investigation: investigating officers require better training to investigate and help to build a strong case for the prosecution; the investigating officer needs to be well-versed in the statutory presumptions as well as establishing a prima facie case so that no evidence is left unturned; the investigating officer and the prosecution need to be able to anticipate the common defences raised in a section 39B case so that they can eliminate any reasonable doubts which could arise. Although litigation is a 'gamble' as no one can guarantee its outcome, an exhaustive investigation to facilitate a well prepared prosecution would ensure the results in convicting an accused person charged with section 39B DDA. The mere fact of imposing death penalty as a punishment to curb drug trafficking activities would not be an efficient deterrent if the investigation is substandard causing unsuccessful prosecution.

\section{Acknowledgement}

This paper is a work in progress under the Exploratory Research Grant Scheme from the Ministry of Higher Education entitled "Exploring the deterrence effect of death penalty on drug trafficking cases". We wish to express our gratitude to the Ministry of Education for awarding the grant and to Universiti Teknologi MARA (UITM) for the co-operation given.

\section{Corresponding Author}

Ekmil Krisnawati Erlen Joni, Department of Law, Universiti Teknologi MARA (UiTM) Cawangan Melaka, Malaysia. Email: ekmil777@melaka.uitm.edu.my. Universiti Teknologi MARA (UiTM) Cawangan Melaka, KM 26 Jalan Lendu, 78000 Alor Gajah. Melaka, Malaysia.

\section{References}

Malik, A. I. (2000). Drug Legislation in Malaysia. Current Law Journal, 3, 81-82

Malik, A. I. (2001). Drug Laws and Ramifications of Drugs Activities in Asean Nations - A Synopsis. Current Law Journal, 4 , 41-43

Malik, A. I. (2009). Human Rights and The Malaysian Judicial System. Current Law Journal, 2, xxi.

Abdullah, H. (2009). Criminal Trial Advocacy for the Defence. Johor Baru, Malaysia: Hisham Bin Abdullah @Teh Poh Teik.

Abdullah, H. (2006). The Law on Drugs Possession and Trafficking in Malaysia. Kuala Lumpur, Malaysia: Marsden Law Book.

Blackstone, W. (1975). The Commentaries on the Laws of England. Oxford: The Clarendon Press.

Clarkson, C., Keating, H., \& Cunningham, S. (2007). Clarkson and Keating Criminal Law: Text and Materials. London: Sweet \& Maxwell.

Edwin, C. (1998). Beyond Reasonable Doubt: The Golden Thread Weakened? Current Law Journal, 1, i -iii.

Nini, F. D. (2006). The Standard of Proof at the Close Prosecution's Case: Is the Question Finally Resolved?. Current Law Journal, 3, Ixxxv.

Mooi, H. C. (2007). Sentencing Practice in Malaysia. Petaling Jaya, Selangor: Sweet \& Maxwell. Asia. Kamaruddin, A. R. (2007). The Misuuse of Drugs in Malaysia: Past and Present. Jurnal Anti Dadah Malaysia (Malaysian Anti-Drugs Journal), 1 (2), 1-24. 
INTERNATIONAL JOURNAL OF ACADEMIC RESEARCH IN BUSINESS AND SOCIAL SCIENCES

Vol. 10, No. 3, March, 2020, E-ISSN: 2222-6990 @ 2020 HRMARS

Khaira, H. S. (2005). Sentencing of Drug Offenders (A Comparative Study of the Australian and Malaysian Approach). Malayan Law Journal, 3, Ixxvii.

Kwai, M. W. (1981). Should Death Penalty Be Abolished? Current Law Journal, 1, 25-27.

Hanum, N. A. M. (2006). Should Death Sentence be Abolished?. Malayan Law Journal, 3, cxliii.

House of Representatives Parliamentary Debate. (1983). March 24 Debate. $2^{\text {nd }}$ and $3^{\text {rd }}$ Reading of the Dangerous Drugs (Amendment) Act, 7404-7460.

Rubin, M. (1996). Standard of Proof Relating to Sufficiency of Evidence at Criminal Trial : Mental Gymnastic Since Haw Tua Tau. Current Law Journal, 2, Ixiv.

Sydney, L. H. (1991). Death, Drugs and Development : Malaysia's Mandatory Death Penalty for Traffickers and International War on drugs. Colombia Journal, 365 - 405.

Teoh, K. C. (2003). The Deterrence Effect of Mandotary Death Sentence in Drug Cases in Malaysia. (Unpublished master's thesis). University Malaya, Kuala Lumpur, Malaysia.

Vijayandran, T. (2012). Mens rea Posession. Malayan Law Journal, 6 , Ixiv. 